\title{
Foreign Policy Making and the U.S. Vision of European Integration in the Nixon Era
}

\author{
Hang Nguyen
}

\section{Abstract}

This paper offers an insight into Washington's foreign policy establishment and its vision of European integration under the Nixon administration. It argues that President Nixon and his National Security Advisor, Henry Kissinger, managed to formulate many important aspects of foreign policy at the White House. From a realist perspective, the Nixon-Kissinger team saw the emergence of a new world order and in it the evolvement of European integration in a way different from previous U.S. administrations. The paper begins by discussing the Nixon administration's realist approach to foreign policy before analyzing President Nixon's determination to make decisions on foreign relations at the White House. Next, the paper examines the main features of the Nixon-Kissinger team's vision of European integration. It concludes that, as realists, the Nixon administration supported integration in Western Europe, yet Washington was ambivalent if a united Europe with increasing self-confidence and self-assertiveness would be in the U.S. national interest. Henceforth, the European integration process had to be, in the Nixon-Kissinger view, taking place under U.S. control in the form of the consultative mechanism and the U.S. military umbrella.

\section{KEY WORDS:}

Nixon administration, European integration, foreign policy, consultative mechanism, European Economic Community 
President Richard Nixon, in office from 1969 to 1974, left a visible mark on U.S. foreign policy making during his term in office. Nixon preferred to formulate U.S. foreign policy with only a few National Security Council officials and ignored traditional diplomacy insisting that U.S. decisions on foreign affairs were to be made at the White House. With the advice and assistance from Henry Kissinger, his National Security Advisor, President Nixon became the key foreign policy maker in the U.S. administration at the time. This led to the centralization of foreign policy making in the hands of the President and his National Security Advisor. This characteristic of U.S. foreign policy making in the Nixon presidential years contributed to the changed nature of the U.S. vision of the process of European integration. An examination of archival records reveals two important views of the Nixon administration regarding European integration: The U.S. embraced the emergence of a European community in the multi-polar international order while the evolution of such a community on the other side of the Atlantic Ocean was expected to occur under U.S. leadership. This paper sheds light on the main features of the Nixon administration's foreign policy making before concentrating on the process of European integration from the U.S. perspective. Having looked at Europe and the world through realist lenses, the Nixon administration had a fresh view of U.S. national interests and threats in a changing world environment, and thus developed a new image of European integration that would help the Nixon administration to perpetuate U.S. interests and defend its nation from potential dangers.

\section{Nixon's realist approach}

U.S. foreign policy making in the Nixon presidential years was framed by a realist approach which seeks to maximize the realization of states' national interests. Through the lenses of a realist, the discipline of international relations studies nation-states competing for survival, predominantly making use of military power in the pursuit of this goal. In other words, the realist approach is built on four main assumptions: (i) nation-states are the principal actors in global politics (ii) self-interest is the main motivation for nation-states' actions (iii) the main concern of nation-states is the balance of power in the international system; and (iv) it is the relationship 
between or among nation-states (not domestic politics) that decides how one nation-state reacts to the others (McCormick 2010: 102).

Realists stress the constraints placed on politics by human nature and the state of anarchy in the international system. The combination of these two factors makes international relations a domain full of power and interest. Morgenthau, a leading theorist of realism, once emphasized that "human nature has not changed since the days of classical antiquity" (Morgenthau and Thompson 1985: 17). In the realist view, human nature is basically egotistical, and therefore is prone to immorality. This had been put forth by Machiavelli, in politics "it must be taken for granted that all men are wicked and that they will always give vent to the malignity that is in their minds when opportunity offers" (Machiavelli 1979). According to the realist approach, morality in the realm of foreign affairs is fundamentally decided by what is good for the nation-state and its position in world politics. Thus, foreign policy in the realist view is full of conflicts. Nation-states do the maximum to protect and foster their own interests and watch the other nation-states' activities with wariness. Power politics become dominant in global politics because the key concerns of every nation-state are the distribution of power and the maximization of its own power.

The Nixon administration's foreign policy was more realist in its approach than that of previous presidents (McCormick 2010: 103). It was built on the balance of power among the United States, the Soviet Union, China, Western Europe and Japan. The goal was to make the United States reduce the cost of global hegemony and make use of a large amount of regional power to further U.S. interests. In this way, the United States would sustain its predominance in world politics. Especially, the politics of Nixon influenced the process of Western European integration and made crucial decisions with respect to the war in Vietnam, détente with the Soviet Union and the opening towards China. Together, they made the Nixon administration build a distinctive foreign policy with new focuses.

The difference in the Nixon administration's foreign policy was clearly stated in its first State of the Union on 18 February 1970, which was selfreflected by President Nixon as "more than a record of one year. It is this Administration's statement of a new approach to foreign policy to match a new era of international relations" (Nixon 1970). President Nixon and his 
administration judged that building a long lasting peace needs a foreign policy guided by three fundamental principles:

"-- Peace requires partnership. Its obligations, like its benefits, must be shared. This concept of partnership guides our relations with all friendly nations.

-- Peace requires strength. So long as there are those who would threaten our vital interests and those of our allies with military force, we must be strong. American weakness could tempt would-be aggressors to make dangerous miscalculations. At the same time, our own strength is important only in relation to the strength of others. We - like others - must place high priority on enhancing our security through cooperative arms control.

-- Peace requires a willingness to negotiate. All nations - and we are no exception - have important national interests to protect. But the most fundamental interest of all nations lies in building the structure of peace. In partnership with our allies, secure in our own strength, we will seek those areas in which we can agree among ourselves and with others to accommodate conflicts and overcome rivalries. We are working toward the day when all nations will have a stake in peace, and will therefore be partners in its maintenance" (Nixon 1970).

These three principles implied that the United States would reduce its global responsibility and engage other states to share the burden of preserving the world order. This new approach to foreign policy also implied that the Nixon administration would defend U.S. interests by using its military power. In addition, it implied that the United States would prefer negotiations as the policy of choice in dealing with various international issues. In general, this U.S. foreign policy was to a large extent different from that in the postwar administrations which placed much emphasis on U.S. ability and responsibility to carry the burden for building a "Free World" (Fousek 2000: 130). Richard Nixon took office during an unusually fluid time in global politics: The economies of Western Europe, Japan, and China, ruined by World War II, had recovered fast in the late sixties. With the emergence of new economic powers and centers, the bipolar power structure of the 
postwar era, dominated by the United States and the Soviet Union, had been replaced by a multi-polar world. Even though the United States was still the most powerful state in the world, the relations with the Soviet Union and China, and the Vietnam War had shown the limits of its strengths. The grand strategy, developed by President Nixon and National Security Advisor Henry Kissinger to adjust U.S. foreign policy to the new multi-polar system was deeply rooted in realism. The core of this strategy was to expect U.S. allies to pay for their own military defense, though the United States remained willing to aid in defense if necessary. The Nixon administration desired to pursue peace through sustaining a partnership with U.S. allies:

"First, the United States will keep all of its treaty commitments.

Second, we shall provide a shield if a nuclear power threatens the freedom of a nation allied with us or of a nation whose survival we consider vital to our security.

Third, in cases involving other types of aggression, we shall furnish military and economic assistance when requested in accordance with our treaty commitments. But we shall look to the nation directly threatened to assume the primary responsibility of providing the manpower for its defense" (Nixon 1969).

This realist response to the new situation actually reflected their strategic goal: the balance of power.

Richard Nixon was considered as a President who arrived at the White House with more knowledge of foreign affairs than previous ones. He once stated clearly: "I've always thought this country could run itself domestically without a president. All you need is a competent cabinet to run the country at home. You need a president for foreign policy; no secretary of state is really important; the president makes foreign policy" (Small 1999: 59). In reality, foreign policy drew his attention the most during his presidency (Hoff 1994: 4).

Confronting the global developments of the late 1960s, President Nixon and his administration designed a new foreign policy approach for the United States based on the principles of the balance of power. Though 
global politics of the late 1960s was typically described as a rigid, bipolar period with an international system split into two hostile blocs, the Nixon administration saw the emergence of new powers: Japan, China and Western Europe. In addition to the United States and the Soviet Union, these would-be powers would escalate the changing contour of world order. A pentagonal balance would characterize the global political, economic and military structure as President Nixon indicated:

"...as we look ahead 5, 10, and perhaps 15 years, we see five great economic superpowers: the United States, Western Europe, the Soviet Union, mainland China, and, of course, Japan.... These are the five that will determine the economic future and, because economic power will be the key to other kinds of power, the future of the world in other ways in the last third of the century."

This vision of a future world order inspired the Nixon administration to encourage the development of a balance of power in the modern world through U.S. détente with the Soviet Union, the normalization of political relations with China and more evenhanded relations with Japan and Western Europe. President Nixon explicitly explained the views of his administration's foreign policy as follows:

"We must remember the only time in the history of the world that we have had any extended period of peace is when there has been a balance of power. It is when one nation becomes infinitely more powerful in relation to its potential competitor that the danger of war arises. So I believe in a world in which the United States is powerful: I think it will be a safer world and better if we have a strong healthy United States, Europe, Soviet Union, China, Japan, each balancing the other, not playing one against the other, an even balance" (In an interview published in Time magazine on 3 January 1972).

"The only alternative to a balance of power is an imbalance of power... and history shows us that nothing so drastically escalates the danger of war as such an imbalance" (Nixon 1972: $1110-1111$ ) 
National Security Advisor Henry Kissinger even made it clearer in his address to the Commonwealth Club and the World Affairs Council of Northern California on 3 February 1976:

"We must strive for equilibrium of power, but we must move beyond it to promote the habits of mutual restraint, a coexistence, and, ultimately, cooperation. We must stabilize a new international order in a vastly dangerous environment, but our ultimate goal must be to transform ideological conflict into constructive participation in building a better world" (Kissinger 1976).

With such a realist approach to foreign policy, the Nixon administration achieved significant diplomatic successes: ending the Vietnam War, signing the first major arms control agreement with the Soviet Union (SALT I), and opening up towards China. This realist approach to foreign policy during the Nixon administration reflected a fundamental departure from the policy stance in the U.S. leadership during the postwar period.

Along with a realist approach to foreign policy and a fresh view of the role of the U.S. in a new world environment, the Nixon administration reevaluated the U.S. position to redefine its national interests and threats. In his well-known book "Strategies of Containment: A Critical Appraisal of American National Security Policy during the Cold War" published in 1982, John Lewis Gaddis argued that Nixon and Kissinger redefined what constituted threats. In previous administrations, threats were defined in terms of an enemy's ideology. This was because ideology determined behavior (Gaddis 1982: 282). The Nixon administration's definition of threats was fundamentally based on an enemy's actions. In a White House press briefing on 18 December 1969, Kissinger stated that: "We have always made it clear that we have no permanent enemies and that we will judge other countries, including Communist countries, and specifically countries like Communist China, on the basis of their actions and not on the basis of their domestic ideology" (Kissinger 1979: 192). Implicitly, the Nixon administration claimed that the fact that the United States and the Soviet Union had two different ideologies, capitalism and communism respectively, did not constitute a threat to Washington. However, the combination of both hostility and capability embedded in the foreign policy of the Soviet Union was threatening to the U.S. 
Along with a change in understanding what constituted a threat, the Nixon administration reshaped the relationship between threats and interests. In the preceding administrations, perceived threats would define policy interests, particularly the threats from communism. Henceforth, containment of communism had become an interest in and of itself without considering "the precise way in which communism as a unified force might endanger American security" (Gaddis 1982: 105). Yet, the Nixon administration placed emphasis on defining what they thought to be the national interest and then defined threats to be what would harm that national interest. This redefinition allowed the Nixon administration to have more freedom in building and developing foreign relations with communist nation states. As Gaddis observed, the United States was able to "feasibly work with states of differing, even antipathetic, social systems as long as they shared the American interest in maintaining global stability" (1982: 283).

\section{Foreign policy made at the White House}

Bureaucratic resistance has been what U.S. Presidents have to overcome to achieve their desired policy. Even if there is no resistance from bureaucratic bodies, the process of implementing policies is likely to produce outcomes which are not the same as a President's policy preferences. As a result, U.S. Presidents tend to employ administrative strategies to exert an impact on the making and implementation of foreign policy.

During his term in office, President Nixon and National Security Advisor Henry Kissinger were the leading figures in the making of U.S. foreign policy. In his memoirs, Nixon recalled: "From the outset of my administration... I planned to direct foreign policy from the White House. Therefore, I regarded my choice of a National Security Advisor as crucial" (Nixon 1990: 349). From his observation, Robert Dallek reflected in "Nixon and Kissinger: Partners in Power" that: "On the administration's third day in office, Henry began implementing Nixon's plan to ensure White House dominance of foreign policy" (Dallek 2007: 100). On 1 September 1969, President Nixon sent a telegram to Secretary of State (Rogers), Secretary of Defense 
(Laird) and Director of Central Intelligence (Helms) from Colorado Springs (Colorado) where he was attending a National Governors Conference to instruct these senior officials that all public communications and official communications had to be cleared by the White House.

"I have been disturbed in recent days by the lack of teamwork in the conduct of national security affairs. Consequently, I am reaffirming my policies with respect to this matter.

1. Public statements and press releases: Prior to release, all public communications on matters of known or potential Presidential interest must be carefully cleared by the White House (Assistant to the President for National Security) for consistency with Presidential policy and for coordination with the Departments and agencies who share overlapping interests and responsibilities. Should there be any uncertainty as to Presidential or interdepartmental interest, it will be resolved in favor of clearance. 2. Official communications: All official communications with policy implications must be cleared by the White House. When in doubt, the rule is that messages will be so cleared. This procedure requires close and confidential staff relationships at all levels between the White House and your Department as well as among Departments."

In the realm of foreign affairs, President Nixon fundamentally based his approach on presidential control. He developed a strategic approach to an administrative presidency which allowed the President to have a powerful role in the supervision of bureaucracy, which was necessary in order to achieve his foreign policy goals. He made a clear statement: "If we were to establish a new foreign policy for the era to come, we had to begin with a basic restructuring of the process by which policy is made" (Nixon 1970).

Accordingly, the power of cabinet members decreased and the power of Nixon's most trusted advisor Henry Kissinger increased. In reality, Henry Kissinger became one of the most powerful men in Washington. Kissinger's offices were set up in the West Wing's basement, "from which he could have easy access to the President" (Dallek 2007: 100). This is also what Richard Helms observed: "they alone would conceive, command, and 
control clandestine operations. Covert action and espionage could be tools fitted for their personal use. Nixon used them to build a political fortress at the White House" (Weiner 2007: 293). Such a centralization of policy making and implementation enabled President Nixon and Kissinger to obtain their policy preferences because they would not have to go through a decision making process with many departments and agencies, and thus they could limit opposition.

Richard Helms, the Director of Central Intelligence from June 1966 to February 1973, supposed that "Richard Nixon never trusted anybody", and that Nixon did not believe in the capacity of departments and agencies such as the Department of State and the Central Intelligence Agency (the CIA), therefore, "Nixon insisted on isolating himself" from the Washington bureaucratic agencies he did not have confidence in.

"Very early in the Nixon administration it became clear that the President wanted Henry Kissinger to run intelligence for him and that the National Security Council staff in the White House, under Kissinger, would control the intelligence community. This was the beginning of a shift of power away from the CIA to a new center: the National Security Council staff" (Ranelagh 1986: 50).

Former Deputy Director of Intelligence at CIA Ray Cline described how the role of the CIA declined during the presidency of Nixon:

"Nixon and his principal assistant, Dr. Kissinger, disregarded analytical intelligence except for what was convenient for use by Kissinger's own small personal staff in support of NixonKissinger policies. Incoming intelligence was closely monitored and its distribution controlled by Kissinger's staff to keep it from embarrassing the White House..." (Cline 1976: 216).

According to Cline, Helms and the CIA were employed mainly "as an instrument for the execution of White House wishes" (Cline 1976: 216).

It is noticeable that Gaddis pointed out that the centralization of policy making and its implementation were crucial in order to attain the Nixon administration's foreign policy agenda. This they accomplished "to a 
remarkable extent, they succeeded [in achieving their goals], but only by concentrating power in the White House to a degree unprecedented since the wartime administration of Franklin D. Roosevelt" (1982: 273).

Saul Landau even showed the existence of "a secret foreign policy apparatus" in the Nixon years. Such an apparatus allowed President Nixon to ignore the established bureaucratic bodies which still saw the Cold War through ideological lenses and were likely to oppose his foreign policy decisions.

\begin{abstract}
"Nixon created a special finance committee with its own funds, the Finance Committee to Reelect the President, headed by commerce secretary Maurice Stans, a White House controlled political grouping independent of the Republican party... and, finally, a secret foreign policy apparatus headed by Kissinger and designed to circumvent the clumsy and stagnant national security bureaucracy" (Landau 1988: 103).
\end{abstract}

Indeed, the foreign policy agenda during the Nixon years was established centrally at the White House and the drivers of the foreign policy making process were President Nixon and his National Security Advisor Henry Kissinger. Accordingly, U.S. views and attitudes towards the European integrative process between 1969 and 1974 were established with great influence from the White House.

\title{
A vision of European integration
}

At the core of the Nixon-Kissinger team's vision of European integration lay the European Community as a force in a multi-polar world. In the evening of 29 July 1967, Richard Nixon delivered a speech to the Bohemian men's club in the Bohemian Grove near San Francisco. In this remarkable address, Nixon evaluated the main forces at work in the world and discussed U.S. foreign policy. Nixon showed that a new world was coming with new leaders, new people and new ideas. A world in which De Gaulle, 
Mao Tse-tung and Chiang Kai-shek were still on the world stage with the U.S., however, new leaders were taking power from Churchill, Adenaver, Stalin, Khrushchev, Nehru and Sukarno. This would be a world in which a new generation would be growing up, a generation born after World War II and thus with no real experience of it. It would be a world in which no "ism" had the potential to imprison peoples and nations on both sides of the Iron Curtain. After depicting to the Bohemian men and the guests the new landscape of the world, Nixon directed their attention particularly to Western Europe:

"Twenty years ago Western Europe was weak economically and dependent on the United States. It was united by a common fear of the threat of Communist aggression. Today, Western Europe is strong economically and economic independence has inevitably led to more political independence. The winds of détente have blown so strongly from East to West that except for Germany most Europeans no longer fear the threat from the East. The consequences of this change are enormous as far as NATO is concerned. As Harold Macmillan puts it, 'Alliances are kept together by fear, not by love'. Even without De Gaulle, the European Alliance would be in deep trouble" (Nixon 1967).

He underlined that Western Europe was in good economic condition. Their economic independence enabled them to design policies unfavorable to the U.S.: The "economic strength of Western Europe thwarted their progressive designs in that area. They faced increased demand for consumer goods from the Russian people. They looked down the nuclear gun barrel in the Cuban confrontation" (Nixon 1967).

Two years later when Nixon arrived at the White House in 1969, his administration reviewed U.S. policy to freer world trade and reaffirmed that the continuation of the policy was in U.S. interest, but emphasized that a number of foreign countries were competing fully with the United States in world markets. This implied that economic competition from Western Europe led to the disappearance of the traditional surplus in the U.S. balance of trade. The United States had been at its peak when the Second World War ended in 1945. Yet, the relative decline in its global predominance was starting to become more evident. This concern had 
been revealed in the Press Briefing by the President's National Security Advisor Henry Kissinger on 18 December 1969:

"For about 20 years after the end of the war, American foreign policy was conducted [through a] Plan, that is, [through] the notion of a predominant United States, as the only stable [country] with the maxims and the inspiration that guided the Marshall country, the richest country, the country without whose leadership and physical contribution nothing was possible, and which had to make all the difference for defense and progress everywhere in the world.

Now whichever Administration had come into office would have had to face the fact, I believe, that we have run out of that particular vision. Conditions have changed enormously. We are now in a world in which other parties are playing a greater role. They have regained some of their self-confidence. New nations have come into being. Communism is no longer monolithic and we, therefore, face the problem of helping to build international relations on a basis which may be less unilaterally American" (Press Briefing, Kissinger 1969).

The U.S. economy was producing less but the other economies were producing more. By the early 1970s, with the shrinking of gold reserves and the rising of inflation, the Nixon administration had to float the dollar against the currencies of other countries which eventually led to a severe depreciation. But the U.S. government under the Nixon administration made a contribution towards promoting a world of multi-polar relations and creating a liberal international environment that was characterized by its open-market and capitalist traditions. In that global setting, the European Community, which was in the process of deeper economic integration, was foreseen by the Nixon administration to be an emerging power and would be an important leverage to create an even balance in the international system.

"When we see the world in which we are about to move, the United States [is] no longer in the position of complete pre eminence or predominance [and] that is not a bad thing. As a 
matter of fact, it can be a constructive thing. ... We now have a situation where four economic powers [the Soviet, China, Japan, and Western Europe] have the capacity to challenge [the U.S.] on every front" (Nixon 1971).

Not only had the Soviet Union gained a military strength comparable to that of the United States, but Japan and Western Europe were vigorous competitors with the United States for markets. This meant that the world was now reaching an order called: a multi-polar world.

Along with his administration's concept of a multi-polar world with five powers, President Nixon sent signals that he would be in support of developing and sustaining the European Community as a pillar in that multi-polar world. After his discussions with French President Charles De Gaulle in 1969, President Nixon indicated his agreement with De Gaulle about building a strong and independent European Community:

"[De Gaulle] believes that Europe should have an independent position in its own right. And, frankly, I believe that too ... the world will be a much safer place and, from our standpoint, a much healthier place economically, militarily and politically, if there were a strong European Community to be a balance ... between the United States and the Soviet Union" (Chace 1973: 96).

President Nixon restated his administration's support for developing the European Community as a balance in the multi-polar world at a National Security Council meeting in the presence of British Prime Minister Harold Wilson in January 1970:

"I have never been one who believes the U.S. should have control of the actions of Europe ... I have preferred that Europe move independently, going parallel with the United States. A strong, healthy and independent Europe is good for the balance of the world" (Doc. 56, FRUS 1969-1976).

National Security Advisor Henry Kissinger also showed U.S. encouragement for deeper integration in the European Community when he stressed that: 
"'Efforts to create a more coherent European voice in our NATO are in net interest'. Kissinger even wrote to President Nixon about European coherence 'European coherence would be quite consistent with what you have said about the desirability over the longer run of our being able to deal with Europe as a true and more equal partner'"(Kissinger 1979: 385).

This U.S. perspective of the integration process in the European Community was clearly summarized in Nixon's Report to Congress on 18 February:

"We favor a definition by Western Europe of a distinct identity, for the sake of its own continued vitality and independence of spirit. Our support for the strengthening and broadening of the European Community has not diminished. We recognize that our interests will necessarily be affected by Europe's evolution, and we may have to make sacrifices in the common interest. We consider that the possible economic price of a truly unified Europe is outweighed by the gain in the political vitality of the West as a whole" (Nixon 1970).

Though encouraging the development of European unity in a multi-polar world in which the main pillars (the European Community, the United States, Japan, the Soviet Union and China) represented equal forces and strengths to sustain the structure of peace in international politics, President Nixon still wanted to prolong the spirits of previous U.S. administrations that was to keep London, Berlin and Paris under Washington's influence. Discussing the future U.S. agenda as the United States worked with Western Europe to build a stable world order, the Nixon administration placed emphasis on the transformation from predominance to partnership and affirmed the importance of enhancing the cooperation in political and economic relations between the United States and the European Community as the Common Market grew. In his radio address on 25 February 1971, President Nixon made it clear that:

"In Western Europe, we have shifted from predominance to partnership with our allies. Our ties with Western Europe are central to the structure of peace because its nations are rich in tradition and experience, strong economically, vigorous in diplomacy and 
culture; they are in a position to take a major part in building a world of peace... Our ties were strengthened on my second trip to Europe this summer" ( Doc 85, FRUS 1969-1976).

Yet, it is undeniable that U.S. policy towards European unity under the Nixon administration was mainly shaped by the fear that a strong and independent European Community would not be conductive to a healthy Atlantic alliance and to a strong partnership between the United States and Western Europe. This was underlined in President Nixon's statement:

"The structure of Western Europe itself - the organization of its unity - is fundamentally the concern of the Europeans. We cannot unify Europe and we do not believe that there is only one road to that goal. When the United States in previous Administrations turned into an ardent advocate, it harmed rather than help progress" (Nixon 1970).

The ambivalence that the European Community would be likely to emerge into a counterweight to the U.S. was greater with the development of Gaullism in France and particularly with the establishment of the European Political Cooperation (EPC) in 1970, whereby Western European countries were able to realize their goal of creating a European foreign policy. Confronting the assertiveness of Western Europe in foreign policy and diplomacy, the Nixon administration developed a strategic plan to ensure that Western European countries would have a pro-Atlantic perspective. The real rational behind this plan was to maintain U.S. control and influence over the European integration process, which was captured by President Nixon as "a new and mature partnership":

"I went to Western Europe in February 1969 to reaffirm America's commitment to partnership with Europe.

A reaffirmation was sorely needed. We had to re-establish the principle and practice of consultation. For too long in the past, the United States had led without listening, talked to our allies instead of with them, and informed them of new departures instead of deciding with them. Inspired by the success of the Marshall Plan, we had taken such pride in our leadership of the alliance that we 
forgot how much even the origin and success of the Marshall Plan grew from European ideas and European efforts as well as our own.

After 20 years, the economic prostration, military weakness, and political instability in postwar Europe that had required a predominant American effort were things of the past. Our common success in rebuilding Western Europe had restored our allies to their proper strength and status. It was time that our own leadership, in its substance and its manner, took account of this fact" (Nixon 1970).

In the course of reaffirming America's commitment to partnership with Europe, the Nixon Administration placed a concentration on (i) the U.S. voice in the North Atlantic Alliance and, (ii) the American military umbrella for Western Europe.

\section{The U.S. voice in the North Atlantic Alliance}

U.S. politicians repeatedly declared that they supported the development of European political and economic integration, speaking encouraging words but having no temptation to make suggestions how this course of development should take. Nonetheless, this rhetoric seemingly contradicted reality, as the Nixon administration insisted that European states consult with the United States before making any decisions which could affect U.S. interests.

The alliance between the United States and Western Europe had been seen as the cornerstone of the U.S. postwar foreign policy. It provided a political framework for the U.S. engagement in Europe. It provided a security commitment that allowed Europe to recover from the destruction of the Second World War. It provided support for European unity in an era of prolonged tensions and confrontations. Ultimately, the United States wanted to sustain its predominant role in the alliance. Martin J. Hillenbrand, then the U.S. ambassador to Germany, indicated that the 
Nixon administration wanted to have consultations with Western Europe on issues of mutual concerns before a consensus was reached among the Europeans. Understandably, such ideas and perspectives from the Nixon administration were strongly criticized by Western European countries, particularly France. Western European countries themselves prepared a draft proposal for a Joint Declaration on Atlantic relations without any consultations with Washington on its contents. Especially, at the Copenhagen European Summit in December 1973, the leaders of the nine member states of the European Community affirmed their strong will to introduce the concept of European identity into their common foreign relations. The Declaration on European Identity issued after the summit mentioned that the relationship between the U.S. and the European Community had better be built on the basis of equality.

"The close ties between the United States and Europe of the Nine - we share values and aspirations based on a common heritage - are mutually beneficial and must be preserved. These ties do not conflict with the determination of the Nine to establish themselves as a distinct and original entity. The Nine intend to maintain their constructive dialogue and to develop their co-operation with the United States on the basis of equality and in a spirit of friendship" (Declaration on European Identity, EU Council 1973).

Already disagreeing on how to deal with the Yom Kippur War in October 1973 and the ongoing oil crisis, European statements of this kind indicated that Western European countries did not want to subordinate their interests to the United States. As a consequence of such tensions, the United States persuaded the government of Willy Brandt in West Germany to take the lead in the Gymnich formula, an agreement reached at the meeting of foreign ministers at Gymnich castle in West Germany's Rhineland region among the European Community member states on 10 June 1974. The United States was treated in the agreement as a special partner in consultations. Authority was given to the rotating Presidency of the European Community Council to have consultations with the United States on elaborating a common European foreign policy.

"The second point is the question of consultations. The Ministers were agreed that in elaborating common positions on foreign 
policy there arises the question of consultations with allied and friendly countries. Such consultations are a matter of course in any modern foreign policy. We decided on a pragmatic approach in each individual case, which means that the country holding the Presidency will be authorized by the other eight partners to hold consultations on behalf of the Nine.

In practice, therefore, if any member of the EPC [European Political Cooperation] arises in the framework of the EPC the question of informing and consulting an ally or friendly state, the Nine will discuss the matter, and upon reaching agreement, authorize the Presidency to proceed on that basis.

The Ministers trust that this gentlemen's agreement will also lead to smooth and pragmatic consultations with the United States which will take into account the interests of both sides" (Text of the Gymnich Formula 1974).

The Gymnich agreement was viewed as being against French political will as it ensured the presence of the United States in the process of European decision making (Junker et al. 2004: 59). Under pressure from Washington, a consultation mechanism, close to U.S. views, between the United States and the EPC was proposed by Günther van Well, Western German political director:

"If a member state government believes that an issue discussed within the EPC bears on important American interests, the US government should be informed. This should happen once consensus is reached on the matter, but before the decision is formulated in order to give the US government an opportunity to lay out its views, which the EC Nine could take into account during their final discussion round" (Günther van Well 21 March 1974).

This actually repeated what had been made clear in the Declaration on European Identity by the Nine Foreign Ministers, Copenhagen on 14 December 1973. Regarding the relations with the United States, the Nine Foreign Ministers agreed that the constructive dialogue with the United States would be maintained. 
"The close ties between the United States and Europe of the Ninewe share values and aspirations based on a common heritageare mutually beneficial and must be preserved. These ties do not conflict with the determination of the Nine to establish themselves as a distinct and original entity. The Nine intend to maintain their constructive dialogue and to develop their co-operation with the United States on the basis of equality and in a spirit of friendship" (Declaration on European Identity, EU Council 1973).

In addition, the Ottawa Declaration, a new declaration on Atlantic relations, was approved and published by the North Atlantic Council at a ministerial meeting in Ottawa on 26 June 1974. In addition to clauses on economic cooperation and security issues, the Declaration once again reaffirmed the necessity of maintaining the consultation mechanism in the Atlantic alliance:

"The Allies are convinced that the fulfillment of their common aims requires the maintenance of close consultations [...], they are firmly resolved to keep each other fully informed and to strengthen the practice of frank and timely consultations by all means" (Declaration by the North Atlantic Council in Ministerial Session on 19 June 1974).

With a strong determination to have a role in European affairs, the U.S. government placed an emphasis on maintaining consultations between the two shores of the Atlantic. Consultations between the European Community and the United States on economic, diplomatic, political and security issues served as a means to send Washington's messages to Western Europe and formed a basis for Washington to get to know Western European plans and intentions. In case such plans and intentions were in conflict with U.S. interests, Washington would be able to make its opinions heard before an agreement among the Europeans was reached. Ultimately, the Nixon administration maintained its influence on European affairs in general and the European integration process in particular. 


\title{
The U.S. military umbrella for Western Europe
}

The Nixon administration was fully aware of the need of Western Europe for U.S. defense commitments in the region. The crucial role of the United States in protecting Western Europe could be seen through Washington's contribution to NATO. The United States "has two-thirds of NATO's GNP, contributes about half of the direct costs of NATO's defense, and provides the nuclear shield" in Western Europe (Doc 4, FRUS 1969-1974). The Nixon administration hence realized what the Europeans wanted to have on the defense side:

\footnotetext{
"The main objectives of our European allies are (a) to keep the United States physically committed to the defense of Western Europe, so that the engagement of our nuclear power is assured; and (b) to buy a right to be consulted by the United States on anything affecting their security"(Doc 4, FRUS 1969-1974).
}

Nonetheless, the U.S. military umbrella for Western Europe was not taken for granted. The Nixon administration linked its commitments for military presence in Western Europe with certain economic and political conditions:

\begin{abstract}
"Out of this dynamic deal, our allies get not only the protection of our military power but some negotiated degree of participation in US political decisions that affect their destiny. By committing our resources and sharing our discretion in limited ways, we try to get our allies not only to do as much as possible for the common defense, but also to support our efforts to build a workable world order, especially by making sensible security arrangements with the Soviet Union" (Doc 4, FRUS 1969-1974).
\end{abstract}

President Nixon indicated very clearly the relation between US defense commitments in Western Europe and the region's trade policy in a cabinet meeting on economic policy on 10 April 1969 in Washington. Discussing with members of the cabinet and particularly with Secretary Maury Stans who was going to have a trip to Europe, President Nixon underscored: 
"Americans and Europeans have had some protectionist problems in the short run, but we have to make clear that this policy cannot be permanent [...]. Our mid-western friends here in America will stick with us on NATO but if we start fooling around with their soy beans, their votes are gone. Maury [Stans], if I were you, I would point out the growing isolationism in America. [...] There is no question about what the new leadership stands for, [...] but we face a political problem at home. If the American people get the impression that the European economy is turning inward, the Europeans can forget about political cooperation; no administration could survive supporting their case" (Doc 19, FRUS 1969-1974).

After a deep analysis of the consequences of the European policy of inwardness or protectionism on the economic situation and political views of the U.S., the 37th President of the United States did not hesitate in directing his Secretary on what to do during the upcoming trip to Europe: "Maury, you have to use great discretion on this and not refer to it publicly at all. But tell them our problem. They don't hesitate to tell us theirs" (Doc 19, FRUS 1969-1974).

The Secretary needed to let the Europeans know that they had to lift their trade restrictions on U.S. exports generally, and U.S. agricultural exports to their market particularly, in return for a U.S. freeze of troop levels in Europe. The President made it clear that the traditional support of the U.S. would be provided on the condition that a united Europe did not counter U.S. interests and the broader framework of Atlantic partnership. The protectionist policy of the European Community was seen by the President and the U.S. Congress as a signal of hostility and confrontation. This was exactly what the United States did not expect to have after making substantial efforts in economic, political and defense spheres for the European countries to be united in prosperity and security. In a nationally televised address on 15 March 1974, President Nixon publicly showed his administration's increasing pressure on Western Europe by connecting military commitment to economic and political performance:

"Now the Europeans cannot have it both on the security front and then proceed to have confrontation and even ways. They 
cannot have the United States participation and cooperation on the security front and then proceed to have confrontation and even hostility on the economic and political fronts [...] In the event that Congress gets the idea that we are going to be faced with economic confrontation and hostility from the Nine, you will find it almost impossible to get Congressional support for continued American presence at present levels on the security front [...] we are not going to be faced with a situation where the Nine countries of Europe gang up against the United States - the United States which is their guarantee for security. That we cannot have" (Nixon 1974).

The strategic connections of economic, political and security interests were a crucial factor in Washington's approach to the European integration process. The Nixon administration was certain that the integrative process in Western Europe could not be smooth and achievable without U.S. military assistance. The threat of a U.S. troop withdrawal from Western Europe was, therefore, put on the negotiation table when the Europeans wanted to pursue a policy which in Washington's view harmed U.S. interests. This was discussed by President Nixon and Henry Kissinger:

\begin{abstract}
"Nixon: And I am going to say too that this is all part of the same situation. The Europeans cannot expect cooperation on the security front where the American role is indispensible to their survival and confrontation and at times even hostility on the economic front.
\end{abstract}

Kissinger: And political front. That I think would be excellent."

(Telcon Kissinger/Nixon 1974)

Believing that without the U.S. military umbrella the European Community would be an economic giant but a military pygmy, the Nixon administration had a strong bargaining tool in its negotiations with the Europeans. The leaders of the European Community were made to understand that their economic and political integration process would be implemented successfully only if they continued to be supported from Washington on the security front. Other concerns must have also been on the mind of President Nixon when he spoke at a Cabinet-level meeting of the Council 
"...have one hell of a time acting as a bloc. They do not get along with each other. The French don't get along with the Germans, the Germans don't get along with the British. It will be some time before they can learn to act as a group. This means we have to work with the heads of government in the various countries and not that jackass in the European Commission in Brussels" (Doc 100, FRUS 1969-1974).

\section{Conclusion}

With a strong interest in foreign policy, President Nixon and his National Security Advisor Henry Kissinger steered the course of U.S. foreign policy making. They shared a well-defined perception of international politics and economics. Being led by realism, the Nixon-Kissinger team was aware of changes that were taking place in the world. The emergence of a new world order made them view the process of European integration somewhat differently from previous U.S. administrations. Though the United States during the Nixon presidential years still supported movements for integration in Western Europe, Washington could not hide its fear that a united Europe with increasing self-confidence and self-assertiveness could oppose U.S. interests. Therefore, European integration had to, in the Nixon-Kissinger view, take place under the influence of the U.S. The consultative mechanism allowed Washington to discuss issues before the European Community made important decisions. By keeping a security commitment to the European Community and by sustaining bilateral relations with the core nations of the Community, the Nixon administration not only maintained strong ties with Western Europe but also ensured that the European integration process would take into account Washington's interests. 


\section{Bibliography}

Chace, J., 1973. The Concert of Europe. Available at: http://www. foreignaffairs.com/articles/24461/james-chace/the-concert-ofeurope [accessed 27 March 2014].

Cline, R. S., 1976. Secrets, Spies, and Scholars: Blueprint of the Essential CIA. New York: Acropolis Books.

Dallek, R., 2007. Nixon and Kissinger: Partners in Power. New York: Harper Collins Publishers.

EU Council of the EU, Document of 14 December 1973. Declaration on European Identity. http://aei.pitt.edu/4545/ [accessed 14 January 2014].

Fousek, J., 2000. To Lead the Free World. New York: UNC Press Books.

Foreign Relations of the United States (FRUS). Foreign Relations of the United States, 1969-1976. Available online: https://history.state. gov/historicaldocuments/nixon-ford [accessed 21 February 2014].

Gaddis, J. L., 1982. Strategies of Containment: A Critical Appraisal of American National Security Policy during the Cold War. New York: Harper Collins Publishers.

Günther van, W., 1974. Proposal on Consultation between the Nine and the United States. CHAN.5AG2 1021.

Hoff, J., 1994. Nixon Reconsidered. New York: Basic Books.

Junker, D., Gassert P., Mausbach W. and Morris, D. B., 2004. The United States and Germany in the Era of the Cold War, 1945-1990: A Handbook, Volume 1 (1945-1968). Cambridge: Cambridge University Press.

Kissinger, H., 1969. The Press Briefing by President's Assistant for National Security Affairs. Available at: http://history.state.gov/ historicaldocuments/frus 1969-76v01/d47 [accessed 21 February 2014].

Kissinger, H., 1976. The Permanent Challenge of Peace: U.S. Policy toward the Soviet Union. An address to the Commonwealth Club and the World Affairs Council of Northern California, San Francisco. 
Kissinger, H., 1979. The White House Years. Boston: Little, Brown and Company.

Landau, S., 1988. The Dangerous Doctrine: National Security and U.S. Foreign Policy. Boulder: Westview Press.

Machiavelli, N., 1970. The Prince. New York: Penguin Group.

McCormick, J. M., 2010. American Foreign policy \& Process, 5th edn. Boston: Wadsworth Cengage Learning.

Morgenthau, H. J., and Thompson K. W., 1985. Politics among Nations: the Struggle for Power and Peace, 6th edn, New York: Alfred E. Knopf.

NATO Official Text of 19 June 1974. Declaration on Atlantic Relations. Available at: http://www.nato.int/cps/en/SID-D2614824-AF4664D6/ natolive/official texts 26901.htm [accessed 12 January 2014].

Nixon, R., 1967. Address to the Bohemian Club. Available at: http://history. state.gov/historicaldocuments/frus1969-76v01/d2 [accessed 23 March 2014].

Nixon, R., 1969. Address to the Nation on the War in Vietnam. Available at: $\quad$ http://www.presidency.ucsb.edu/ws/index.php?.pid=2303 [accessed 16 January 2014].

Nixon, R., 1970. First Annual Report to the Congress on United States Foreign Policy for the 1970's. 18 February 1970, Available at: http://www. presidency.ucsb.edu/ws/?pid=2835 [accessed 17 February 2014]

Nixon, R., 1971. Address to the Media Executives in Kansas City. Available at: $\quad$ http://www.presidency.ucsb.edu/ws/index.php?pid=3069 [accessed 13 January 2014].

Nixon, R., 1971. Radio Address by President Nixon. Available at: http:// history.state.gov/historicaldocuments/frus 1969-76v01/d85 [accessed 13 February 2014].

Nixon, R., 1972. Richard Nixon: 1972: containing the public messages, speeches, and statements of the president. Washington: Office of the Federal Register.

Nixon, R., 1974. President Nixon's nationally televised remarks. 15 March 1974.

Nixon, R., 1990. The Memoirs of Richard Nixon. New York: Simon \& Schuster. 
Ranelagh, J., 1986. The Agency: The rise and decline of the CIA. New York: Simon and Schuster.

Report on Meeting of the Cabinet Committee on Economic Policy of 10 April 1969. Available at: http://history.state.gov/historicaldocuments/ frus 1969-76v01/d19 [accessed 13 March 2014].

Small, M., 1999. The Presidency of Richard Nixon. Lawrence: University of Kansas Press.

Telcon Kissinger/Nixon, 15 March 1974, 11 am, NPM, NSC, Kissinger files, Tecons, 25.

Telegram from the Mission to the North Atlantic Treaty Organization to the Department of State. Brussels 23, January 1969. Available at: http:// history.state.gov/historicaldocuments/frus 1969-76v41/d4\#fnref3 [accessed 3 January 2014].

Text of the Gymnich Formula, 10-1 1 June 1974. Available at: http://hist.asu. ru/aes/EFP Documents 0415158222.pdf. [accessed 19 March 2014].

Weiner, T., 2007. In Legacy of Ashes: The History of the CIA. New York: Harper Collins Publishers.

Hang Nguyen (thuyhang032003@gmail.com) is a lecturer at the Diplomatic Academy of Vietnam. She obtained an MA with distinction in International Studies from the University of Sheffield (UK) in 2011 . She has research interests in U.S. foreign policy, European integration, Europeanization and globalization. Presently, she is conducting a research project on U.S. policy towards European integration from 1969 to 1974 at the School of Global, Urban and Social Sciences, the Royal Melbourne Institute of Technology, Australia. Her research entitled "U.S. foreign policy towards European integration, 1969 -1974: A new understanding" aims to examine the changes and continuities in U.S. policy towards European unification under the Nixon administration, analyze the impacts of such changes on the relations between the United States and the European Economic Community and draw lessons for countries in relations with the United States and the European Union in the present time. 